Kong. Res. J. 4(1) : 132-139, 2017

ISSN 2349-2694

Kongunadu Arts and Science College, Coimbatore.

\title{
ASSESSMENT OF BACTERIA IN AQUAPONICS BY CULTURE DEPENDENT TECHNIQUES
}

\author{
Sheema, K.K. and M. Dorai \\ Department of Botany, Government Arts College, Udhagamandalam The Nilgiris-643 002, Tamil Nadu.
}

\begin{abstract}
Aquaponics is an intensive sustainable food production system that combines aquaculture and hydroponics, in which fish and plants grow together symbiotically. In an aquaponic unit, the effluent rich nutrients derived from nitrogenous waste excreted from fish, fish feed and decomposing organic matter, fertilizes hydroponic beds providing essential nutrients for plant growth. Simplified raft aquaponic system vary greatly in design and construction, but perform all key functions of plant and fish production, removal of suspended solids and bacterial nitrification. All life forms require nitrogen as an integral part of proteins and nucleic acids, therefore all living organisms are involved in the nitrogen cycle. This process is primarily accomplished by two groups of autotrophic nitrifying bacteria that can build organic molecules and utilize $\mathrm{CO} 2$ as the carbon source for biosynthesis and oxidation of nitrogen compounds as the energy source. A broad range of major parameters and factors affecting bacterial growth has been studied in this paper which are essential for nitrification, that include healthy biofilter with appropriate water conditions like, water temperature, $\mathrm{pH}$, dissolved oxygen (DO), total nitrogen concentrations. Characterization and identification of bacterial populations in an aquaponics system has been carried out by cultivation-dependant techniques and traditional methods of analyzing microbial communities using standard light microscopy.
\end{abstract}

Keywords: Raft Aquaponic system, Nitrification, biofilteration, biofilm, mineralization.

\section{INTRODUCTION}

The word 'aquaponics' is derived from a combination of 'aquaculture' (fish farming) and 'hydroponics'(growing plants without soil), refers to a bio-integrated system linking recirculating aquaculture with hydroponic production of plants. A brief history of aquaponics and its evolution has been provided Aquaponics is a new paradigm of adopting advanced technologies to practice and increase agricultural productivity (Jones, 2002). Smart farming entails the application of new technique of raising fish and growing vegetables in one unit of infrastructure system there by wisely conserving earth resources (Tangonan, 2012). Aquaponics is relatively a new concept of producing nutritious food which integrates two proven cultures, with a reliable production system which uses minimum water supply in non-soil media under unproductive space (Connolly, 2010). Water replacement comes from negligible losses due to plant evapo-transpiration and atmospheric evaporation (Lennard and Leonard, 2006). The selection of plant species are related to the stocking density of fish tanks and subsequent nutrient concentration of aquacultural effluent (Sace and Fitzsimmons, 2013), Common greens (Celery, Lettuce, Basil) do well in aquaponic systems, plants yielding fruit (tomatoes, bell peppers and cucumbers, beans, peas, and squash) have a higher nutritional demand, which perform better in a higher stocked, well established aquaponic system (Rakocy, 1999a). Freshwater systems rely on three major elements like freshwater aquatic animals, plants and nitrifying bacteria. Aquaponics system consist of a fish tank with one or more grow beds for vegetable production. Biological water filtration removes nutrients that are generated from the feces of fish, decomposing feed, which act as liquid fertilizer for plants and the hydroponic beds function as biofilters. Bacteria in the gravel have a critical role in the cycling of nutrients, without these organisms, the system would stop functioning (Rakocy, 1999a; Diver, 2000). Nitrification is a key microbial process in N-removal and is carried out by the chemolithoautotrophic nitrifying bacteria in aquaponic systems (Stief et al., 2009; Beaulieu et al., 2011). The overall functioning of an aquaponic system depends upon ammonia-oxidising bacteria (AOB) and nitrite-oxidising bacteria (NOB). In the aquaponics system during the process of fish respiration, oxygen and carbon dioxide are exchange $\mathrm{d}$ and ammonia from the fish excrete is converted into nitrite and nitrate by bacteria. which in turn is used by the plant for its growth. The nitrifying bacteria convert the waste excreted by the fish which contains carbon dioxide and nitrogenous compounds (John and Fred, 2012). Carbon dioxide 
return to the water via fish gills are then used as the primary carbon source by the photoautotrophs present in the system (Mills, 1987). The two step process of nitrification occurs as follows: 1) $\mathrm{AOB}$ bacteria convert ammonia $\left(\mathrm{NH}_{3}\right)$ into nitrite $\left(\mathrm{NO}_{2}-\right)$

2) NOB bacteria then convert nitrite $\left(\mathrm{NO}_{2}-\right)$ into nitrate $\left(\mathrm{NO}_{3}-\right)$ (Noophan et al., 2009). Therefore, a healthy bacterial colony is essential for the functioning of aquaponic system. Nitrifying bacteria usually show low maximum growth rates, low substrate affinities thus have long generation times due to low energy yield from their oxidation reactions, have evolved to become extremely efficient in converting ammonia and nitrite.

\section{MATERIALS AND METHODS}

An experiment was conducted to know about the nitrification process in aquaponic system. A study was conducted at indoor Coonoor, Nilgiris, Tamilnadu, India. The system was operated with fishes and plants (starting from November 2013) and water from river-Pykara was the source experimented with for a period of six months. Glass microscope slides were placed in two locations of the aquaponic system as a substrate for biofilm development, where the growth of micro-organisms occurs. Three slides for each of the triplicate systems were attached to a plastic tray utilizing aquarium grade silicon were placed at the bottom of the tank containing the common carp (Cyprinus carpio L.) has been setup. This gave a total of 36 slides from the entire system. Three slides were removed weekly from every set of systems arranged. Fish carp juveniles ( 15 no.) weighing an average of $10.0 \mathrm{~g}$ each, with $9 \mathrm{~cm}$ in length were acclimated and transferred to a $40 \mathrm{~L}$ polystyrene tank. Standard feed of $2 \%$ of its body weight was fed twice daily. An aerator was installed in the unit. Holes are cut in the sheet to accommodate small plastics pots. The bottom and sides of the pots are perforated sufficiently to permit easy movement of the plant roots into the nutrient water. Five plant pots are inserted into the holes of the Styrofoam sheets. The pots are filled to a height one inch below the top with small size gravel, the bottom of the pots remains immersed in the water which acts as the media for the hydroponics component. Leafy green vegetables of three weeks growth purchased from a local nursery are then planted in the pots on the Styrofoam raft. Stocking density was measured in units of fish biomass per volume of water ${ }^{3}$. The stocking density, fish health, fish feed are important aspects for the functioning of the system, where aeration and water exchange renew dissolved oxygen supplies, which remove waste and increase the growth of bacteria in the system.

System Components-Aquaponic unit (aquaculture part) for raising fishes are rectangular water tank (size- $45 \mathrm{~cm}$ breadthx $33 \mathrm{~cm}$ length $\mathrm{x} 27 \mathrm{~cm}$ height) with volume of 40 litres capacity, aquarium air pump 220-240 voltage with power of 5 watts,output-6 litre/minute, frequency-100 $\mathrm{Hz}$ and ( hydroponics part) for growing plants. Floating or raft hydroponic sub system is ideal for the cultivation of leafy and other types of vegetables Plants are grown in hydroponic component that utilizes the nutrient rich water. Depending on the sophistication and cost of the Aquaponics system, the units for solids removal, biofiltration, or the hydroponics subsystem may be combined into single unit The above system operation was started with the introduction of fishes into the aquaculture tank and placing the raft on top of the aquaculture tank. Closed-cell polystyrene sheets support vegetables at the water surface with roots suspended in the culture water .The fishes were fed without planting anything in the pots for a period of two weeks to allow the microorganisms to grow in the media bed inside the pots. Temperature of the water in the tank is monitored using a Jumbo Thermometer. Weekly observations were made of the $\mathrm{pH}, \mathrm{DO}$, Nitrite, Nitrate and total ammonia nitrogen (TAN) of the water using standard kits. A number of hydroponic systems have been used in aquaponics

Biofilteration-Effectiveness of biological filteration increases the efficiency of the nitrogen cycle. Biological filters in aquaponics create an environment to grow microorganism. Nitrification in the bacterial film of the biofilter is affected by a variety of parameters such as temperature, $\mathrm{pH}, \mathrm{DO}$ concentration, alkalinity, salinity, substrate and organic matter (Satoh et al., 2000; Chen et al., 2006). A major concern in aquaponics is, biofilteration were the conversion of metabolic waste product excreted through the gills of fish are broken down into smaller particles, converting the organic macromolecules into nutrients. The media bed with solid particles forms a complex matrix which is the primary site for bacterial growth. Bacteria form colonies in the interstitial spaces of the media bed formed of gravel which varying in size to form a thin film known as biofilm. Thus the media bed effectively acts as biofilter. Due to the build-up of biofilm over time, larger bacterial colonies appear. This biofilter has the potential to continue filteration of the solid fish waste and other particles in the water without clogging for extended periods of time. The function of the system depends upon the 
stocking density of fish and proper maintenance of the system (Rakocy et al., 2006).

Biofilm-Biofilms are biological structures that coat the surfaces of submerged substrates and are endemic in aquaculture systems. Since nitrifying bacteria are photosensitive, sunlight can cause considerable harm to the biofilter. Media beds along with biofilm formation around the biofilter, prevents direct sunlight and thus protects bacteria. Bacterial Colonizing occurs in the biofilter which is the preferred settlement of the bacteria with dark environment. The nitrifiers creates a slimy bio-film, as light brown or beige matrix on the biofilter, and have a distinctive odour, but does not smell particularly foul which could indicate other microorganisms. Good biofilms smell earthy, if otherwise, it is an indication of imbalance in the system. These biofilms protect themselves from desiccation and other potential threats. The overall health of the bacteria at any given time need to be maintained by monitoring all parameters for proper functioning of the aquaponic system. The simple method to monitor the bacterial function is by testing levels of ammonia, nitrite and nitrate which provides the information on the health of the bacterial colony. Ammonia and nitrite should always be $0-1 \mathrm{mg} /$ litre in a functioning and balanced aquaponic unit. Imbalance occurs in the system due to too many fishes, excess fish feed and improper filteration. By reducing fish number, fish feeding regime and by increasing the size of the biofilter this problem can be rectified. Even if the system size is balanced, bacterial activity may be slow during winter seasons. Therefore each parameter should be monitored for the effective functioning of the system.

Mineralization-The dissolved nutrients comprises of fish waste from gill excretion, urine, faeces and feed remains that are assimilated by the plants. These bacteria feed on any form of organic material, such as solid fish waste, uneaten fish food, dying plant parts and dead bacteria. Heterotrophic bacteria require similar growing conditions as nitrifying bacteria especially in high levels of DO. They colonize all components of the unit, especially concentrated in the area of solid waste accumulates and utilize dissolved organic carbon as its food source. Most of the fish retain only 30-40 percent of the food they eat, remaining 60-70 percent are released as waste. Of this, 50-70 percent is dissolved waste released as ammonia, and the remaining are organic mixture of proteins, carbohydrates, fats, vitamins and minerals. The heterotrophic bacteria metabolize these solid wastes and release inorganic nutrients into the water, called mineralization which are essential micronutrients, and the microorganisms that decompose solid wastes are antagonistic to root pathogens thus maintain healthy root growth for the plant in the aquaponic system. Chemotrophic bacteria such as Nitrosomonos sp. utilize ammonia as their food source and produce nitrite as end product, Nitrospira grow as long as food source is available, utilize nitrite as a food source and liberates nitrates as waste product. Heterotrophic bacteria grow much faster than the nitrifying bacteria, reproducing in hours rather than days colonize all components of the unit, especially concentrated at the bottom of the tank were solid waste accumulates. Second step of nitrification (NO2 $\rightarrow \mathrm{NO3}$ ), is very sensitive to traces of sulphides are present in sediments and sludges (Joye et al., 1995). Mineralization is important because it releases several micronutrients which favors plant growth in aquaponic system.

Water quality parameters-According to methods described in (APHA, 2005; Hach company, 2003) all the water quality parameters were analysed (Table1). Temperature, pH and DO are the most important factors to be balanced for fish, plants and microbes and these details were recorded using Hach Model HQ40D with digital $\mathrm{pH}$ sensor. Other parameters such as alkalinity, ammonia, nitrite and nitrate were analyzed using the standard methods (Eaton and Franson, 2005). Nitrifying bacteria are extremely susceptible to high concentrations of ammonia, nitrous acid, low DO and pH outside the optimal range (7.5-8.6) (Masser et al., 2009; Villaverde et al., 2000; Ling and Chen, 2005). The optimal water temperature range for nitrifying bacteria is $17-34^{\circ} \mathrm{C}$. This encourages growth and productivity and tend to decrease during colder periods. Therefore nitrite should be more carefully checked to avoid harmful accumulations in the system. The target $\mathrm{pH}$ for aquaponics is $6-7$, for the organisms within this ecosystem. But bacteria work better at higher $\mathrm{pH}$, and function effectively through a water $\mathrm{pH}$ range of 6-8.5.while the optimum $\mathrm{pH}$ for nitrification was 7.5 to 8.0 Nitrifying bacteria need adequate levels of DO to grow healthy and maintain high levels of productivity (Kim et al., 2007). As the oxygen levels decreases beyond $1 \mathrm{mg} / \mathrm{L}$, dissolved oxygen becomes the limiting factor for nitrification (Mao et al., 2008). Nitrification is a (redox) reaction, where the bacteria derive the energy to live when oxygen is combined with nitrogen. Optimum levels of DO are 4-8 mg/litre, which is the required level for fish and plants. Nitrification does not occur if DO concentration drops below $2 \mathrm{mg} /$ litre. Installation of aerators ensures adequate biofiltration in media 
beds of aquaponic systems. For higher $\mathrm{C} / \mathrm{N}$ ratios, the heterotrophic bacteria compete with nitrifiers for available oxygen and space in the biofilters (Michaud et al., 2006). Therefore nitrification necessitates a low $\mathrm{C} / \mathrm{N}$ ratio.

Culture Methods-Cultivation-dependant, traditional methods of analyzing microbial communities in wastewater treatment systems were carried out as plate count or most-probable number counting to determine the abundance of filamentous bacteria, using Gram and Neisser-staining methods (Jenkins et al., 2004). Various mixed bacterial colonies were grown in nutrient agar medium till a pure culture was obtained. It was then isolated and identified using gram staining, motility and biochemical characters.

Table 1. Physicochemical parameters.

\begin{tabular}{|c|c|c|c|c|c|c|}
\hline PARAMETERS & DEC & JAN & FEB & MAR & APR & MAY \\
\hline Temp & 16 & 19 & 20 & 22 & 24 & 26 \\
\hline $\mathrm{pH}$ & 7.59 & 8.40 & 7.07 & 7.2 & 7.5 & 7.85 \\
\hline DO & 7.9 & 7.3 & 6.9 & 6.6 & 6.4 & 6.1 \\
\hline Nitrite & 0 & 0.1 & 0.03 & 0.02 & 0.01 & 0.01 \\
\hline Nitrate & 1.0 & 1.0 & 4.0 & 5.2 & 6.3 & 6.6 \\
\hline TAN & 1.38 & 1.66 & 1.78 & 2.05 & 2.24 & 2.36 \\
\hline Total Alkalinity & 8.0 & 14 & 18 & 32 & 48 & 67 \\
\hline Total hardness & 12 & 20 & 24 & 31 & 42 & 61 \\
\hline Calcium Ca mg/L & 14 & 26 & 37 & 50 & 69 & 78 \\
\hline Magnesium & 11 & 23 & 32 & 45 & 57 & 69 \\
\hline Iron mg/L & 1.48 & 0.17 & 0.74 & 0.98 & 1.21 & 1.38 \\
\hline Manganese & 0.16 & 0.35 & 0.42 & 0.34 & 0.31 & 0.29 \\
\hline Free Ammonia & 1.38 & 1.66 & 1.78 & 2.85 & 5.64 & 9.49 \\
\hline Chloride & 6.0 & 11 & 21 & 38 & 46 & 69 \\
\hline Fluoride & 0.3 & 0.3 & 0.3 & 0.3 & 0.3 & 0.3 \\
\hline Sulphate & 2.0 & 6.0 & 10 & 16 & 19 & 21 \\
\hline Phosphate & 0.16 & 0.94 & 3.95 & 8.52 & 12.1 & 17.9 \\
\hline
\end{tabular}

Table 2. Method of culture and enumeration of bacterial species.

\begin{tabular}{|c|c|}
\hline Procedures & Explanation \\
\hline Collection of biofilm & $\begin{array}{l}\text { Slides were scraped free of biofilm by a scalpel. The biofilm was diluted in a known } \\
\text { volume of deionised water and homogenised using a magnetic stirrer for } 15 \\
\text { minutes. The homegenised diluted biofilm was used for the culture and isolation of } \\
\text { bacteria. }\end{array}$ \\
\hline $\begin{array}{l}\text { Ten-fold dilution of } \\
\text { sample }\end{array}$ & $\begin{array}{l}\text { Four small beakers were filled, each with } 9 \mathrm{ml} \text { of deionised water. } 1 \mathrm{ml} \text { of the sample } \\
\text { was added to the first beaker and mixed thoroughly. } 1 \mathrm{ml} \text { of this solution was added } \\
\text { to the next beaker and so on. This gave four beakers with the dilution factors of } \mathrm{x} 10 \text {; } \\
\mathrm{x} 100 ; \mathrm{x} 1000 ; \mathrm{x} 10,000\end{array}$ \\
\hline $\begin{array}{l}\text { Inoculation of agar for } \\
\text { bacterial culture }\end{array}$ & $\begin{array}{l}\text { Bacteria were cultured on the general medium, tryptic soy agar (TSA) (Buller, 2004; } \\
\text { King et al., 2004; Whitman, 2004) using the streaking method, as described by } \\
\text { (Whitman, 2004) for colony forming unit (CFU) counts and isolation of pure } \\
\text { colonies. Plates for each dilution were inoculated in triplicate }\end{array}$ \\
\hline Incubation of plates & $\begin{array}{l}\text { Agar plates were incubated at } 25^{\circ} \mathrm{C} \text { for } 48 \text { hours (Whitman, 2004). They were } \\
\text { checked at } 24 \text { hours for bacterial growth. }\end{array}$ \\
\hline $\begin{array}{l}\text { Determination of } \\
\text { colony forming units } \\
\text { (CFU) }\end{array}$ & $\begin{array}{l}\text { A darkfield colony counter was employed for enumeration of CFU using the plates } \\
\text { with TSA. Initial and secondary dilutions were multiplied to ascertain the } \\
\text { conversion factor. }\end{array}$ \\
\hline $\begin{array}{l}\text { Isolation of bacterial } \\
\text { colonies }\end{array}$ & $\begin{array}{l}\text { Bacterial species were sorted according to morphological features, Grams stain } \\
\text { (and 3\% KOH test), catalase and oxidase tests 'Bergey's Manual of Determinative } \\
\text { Bacteriology' (Buller, 2004; Bergey and Holt, 1994). }\end{array}$ \\
\hline
\end{tabular}




\section{RESULTS AND DISCUSSION}

The purpose of this study was to make an assessment of bacteria in aquaponics by culturedependant techniques using traditional methods and to create a congenial atmosphere for the colony development of bacteria which helps the growth of plants. The following parameters of water temperature, $\mathrm{pH}$, dissolved oxygen, nitrites, nitrates, Total ammonia nitrogen (TAN) were analyzed to attain a desirable environment for bacteria in the systems. Fish and bacteria prefer a $\mathrm{pH}$ of 7.0-9.0 and most plants grow within 5.8-6.8 desirably. A pH higher than 8 can prevent plants to absorb the nutrients which results in deficiency (Anderson et al., 1989) and beneficial to fish and bacteria. A desirable $\mathrm{pH}$ ranging from 6.0-7.5 is a major limiting factor in aquaponics. Optimal $\mathrm{pH}$ for aqua cultural crops and bacteria are usually productive. In the entire studied period, water temperature and DO were maintained between $16-26^{\circ} \mathrm{C}$ and 6.1-7.9 ppm in all the systems (Mishra and Yadav, 1978). Referred dissolved oxygen as a major component in biochemical changes and effects metabolic activities of organisms. In the present experiment, there was variation in the level of $\mathrm{pH}(7.0-8.4)$ which was favorable throughout the experiment.

\section{Table 3. Results of Bacterial cultures.}

\begin{tabular}{|c|c|c|c|}
\hline SI.No. & ORGANISMS & METHOD & RESULT \\
\hline 1 & P & $\begin{array}{l}\text { BERGY'S MANUAL OF DETERMINATIVE } \\
\text { BACTERIOLOGY }\end{array}$ & $\begin{array}{l}\text { Serratia } \\
\text { marcescens }\end{array}$ \\
\hline 2 & W2 & $\begin{array}{l}\text { BERGY'S MANUAL OF DETERMINATIVE } \\
\text { BACTERIOLOGY }\end{array}$ & Bacillus cereus \\
\hline 3 & $y$ & $\begin{array}{l}\text { BERGY'S MANUAL OF DETERMINATIVE } \\
\text { BACTERIOLOGY }\end{array}$ & $\begin{array}{l}\text { Bacillus } \\
\text { subtilis }\end{array}$ \\
\hline 4 & R & $\begin{array}{l}\text { BERGY'S MANUAL OF DETERMINATIVE } \\
\text { BACTERIOLOGY }\end{array}$ & $\begin{array}{l}\text { Bacillus } \\
\text { megaterium }\end{array}$ \\
\hline 5 & $W_{1}$ & $\begin{array}{l}\text { BERGY'S MANUAL OF DETERMINATIVE } \\
\text { BACTERIOLOGY }\end{array}$ & $\begin{array}{l}\text { Enterococcus } \\
\text { faecalis }\end{array}$ \\
\hline 6 & 0 & $\begin{array}{l}\text { BERGY'S MANUAL OF DETERMINATIVE } \\
\text { BACTERIOLOGY }\end{array}$ & $\begin{array}{l}\text { Micrococcus } \\
\text { luteus }\end{array}$ \\
\hline
\end{tabular}

Table 4. Morphology and Biochemical parameters.

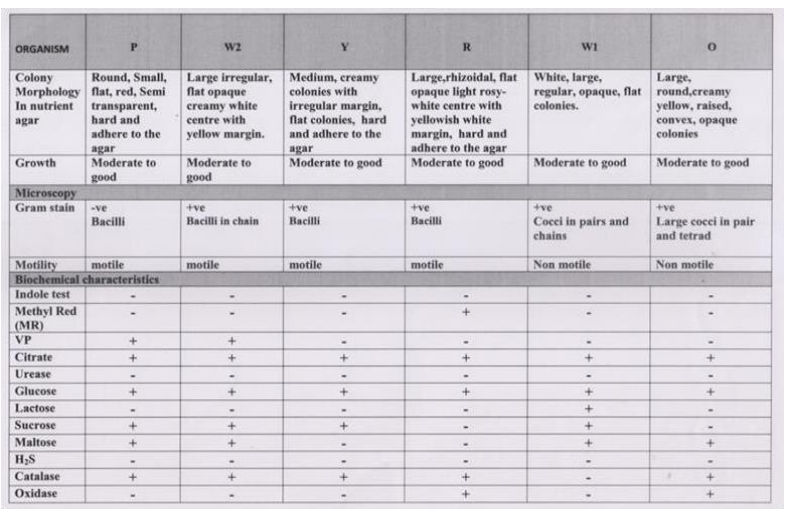

Fig. 1. Colony of Serratia marcescens and Bacillus cereus.

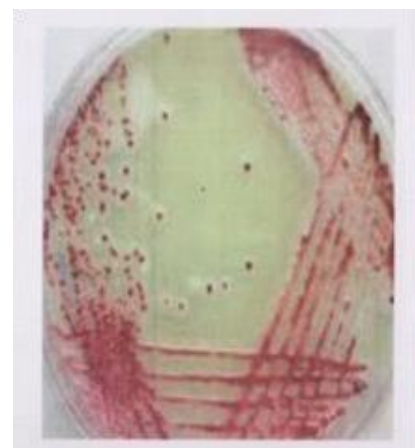

Colony P. Serratia marcescens
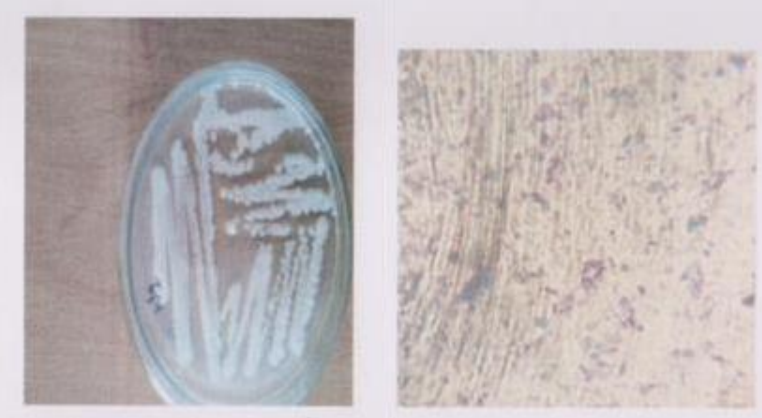

Colony W2 - Bacillus cereus

Fig. 2. Colony of Bacillus subtilis and Bacillus megaterium.
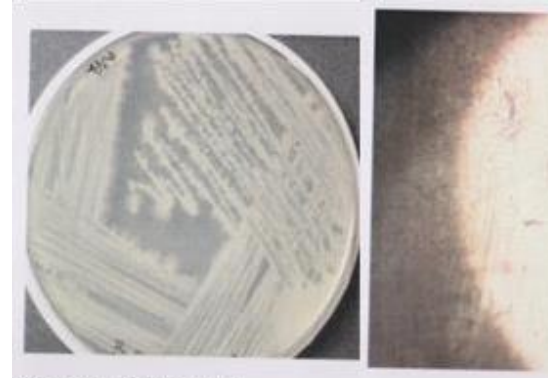

Colony Y - Bacillus subtilis

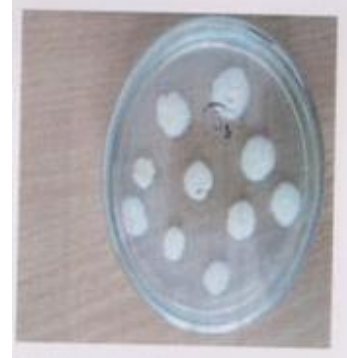

Colony R - Bacillus megaterium

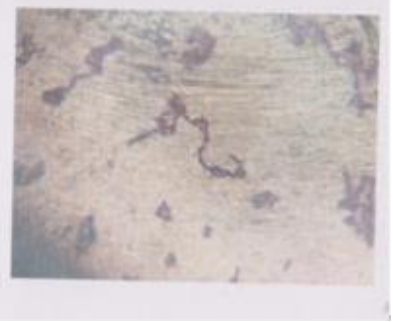

Reduction in $\mathrm{pH}$ was due to the production of $\mathrm{CO} 2$ in water as a result of respiration of fish, bacteria and plant roots in aquaponics system. Spontaneous bacterial colonization occurs in the 
biofilter following the introduction of fish into the system. After one month of time a large drop in NH4 content of the water was observed this refers to the multiplication phase carried out by bacterial population to oxidize larger quantity of $\mathrm{NH} 4$ into NO2. Around third month of the experiment nitrification occurred in a balanced way so ammonia and nitrates remained at low levels which was similar to the report (Petit, 1986). All the three systems remained in equilibrium with stable functioning of NO3 content between 1.0 and 6.6 $\mathrm{mg} / \mathrm{L}$. In this study, the nitrification rate of the system was calculated based on the ammonia removal rate. Microbial nitrification of ammonia to nitrite and nitrate is optimized at $\mathrm{pH} 8.5$ and plant nutrient uptake is optimized near $\mathrm{pH} 6.0$ thus $\mathrm{pH}$ in aquaponic system is maintained near $\mathrm{pH} 7.0$ (Wortman, 2015).

\section{Fig-3: Colony of Enterococcus faecalis and Micrococcus luteus.}

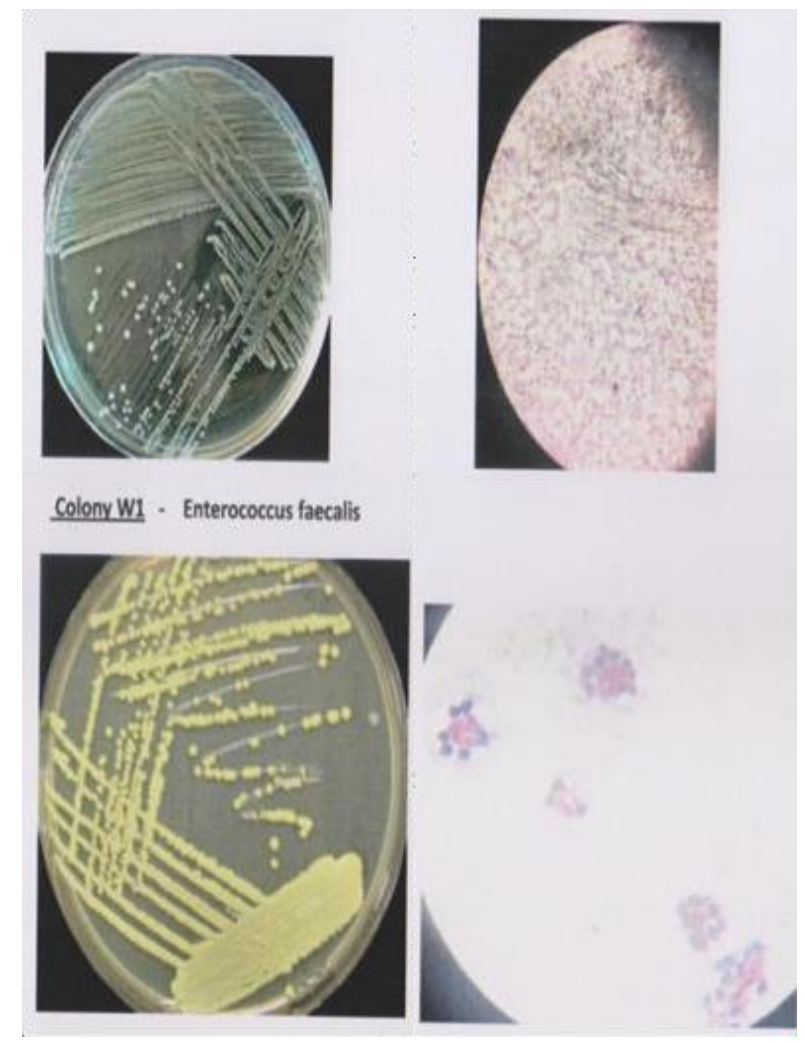

Oxygen is important in waste management because the bacteria breaking down the organic waste require oxygen (Fred, 2002). Several mass balance models in open system have been proposed from previous studies (Pagand et al., 2000; Papatryphon et al., 2005; Mongirdas and Kusta, 2006), from which total nitrogen and phosphorus discharges into receiving waters can be estimated. Recently, the incorporation of recirculated fish with vegetable production has become a new model (Bakhsh et al., 2007; Endut et al., 2009). During oxidation of $\mathrm{NH} 4+, \mathrm{pH}$ increased from 7.1 to 8.45 under high ammonium loads. Free ammonia is NH3, the toxic form of ammoniacal $\mathrm{N}$ which may inhibit the heterotrophic nitrification activity but not the growth.

Heterotrophic nitrification and cellular growth differ according to $\mathrm{pH}$ conditions. Highest removal of ammonium and oxygen demand was presented at $7.5 \mathrm{pH}$. This shows that bacterial growth was preferentially proceeding at high $\mathrm{C} / \mathrm{N}$ ratios, to maintain safety values of ammonium inside the system, which was earlier reported (Leonard et al., 2000; Ren et al., 2014). Enumeration and culture of bacteria in aquaponics system. Bacterial colonies were sorted according to morphological features (Table 3 and 4) were all represented moderate to good growth. Only Serratia marcescens was gram negative stain and the test for motility was recorded with Enterococcus faecalis and Micrococcus luteus. as non motile species. Biochemical reports suggests indole test, urease and H2S with negative results for all the species studied, were as all the species showed a positive result with citrate and glucose tests.(Fig-1,2 and 3)represents the bacterial colonies isolated from the aquaponic system. These media, on volume basis have low capacity for fixing and storing nutrients (Bunt, 1988) but are more consequently fertilized with high amounts of $N$. Due to bioconversion of ammonia by nitrifying bacteria into nitrite and to nitrate there is right balance between fish nutrient production and plant uptake. Careful management of ammonium nutrient sources help one to achieve the desired crop nutrient supply and minimize losses of nitrate. In the beginning of the experiment, there were no enough nitrifying bacteria in the system observed which was similar to the report (Yamamoto et al., 2008) with the growth of $\mathrm{AOB}$, the accumulated TAN oxidized to No2-.was attributed to the different growth rate were AOB increased faster than NOB when there was raise in temp above $25^{\circ} \mathrm{C}$.Nitrifying bacteria are relatively slow to reproduce and establish colonies, requiring days and sometimes weeks or more which is one of the most important management parameters when establishing a new aquaponic system This reveals that water temperature had significant influence on nitrification. Benefit of aquaponics is that organic fish effluent replaces the need for inorganic commercial chemical fertilizers, providing potential chemical free, nutritious products by minimizing the 
need for discharge due to its recirculating nature with the key role by bacteria (Ghaly et al., 2005).

\section{REFERENCES}

Anderson, M., L. Bloom, C. Queen, M. Rottenburg, K. Stroad, S. Sukanit and D. Thomas, (1989). Understanding Hydroponics. VITA Publication. Arlington, Virginia, USA.

APHA, (2005). American Public Health Association (APHA),Standard Methods for the Examination of water and Wastewater, 21 $1^{\text {st }}$ ed. American Public Health Association, Washington, DC.

Bakhsh, Khods, Shariff and Rashid, (2007). Nutrient optimization and computerized decision support program in recirculating integrated aquaculture system. Int. J. Environ. Cul. Eco. Soc. Sustain. 3(5): 25-34.

Beaulieu, J.J., J.L. Tank, S.K. Hamilton, W.M. Wolheim, R.O. Hall, P.J. Mulholland, B.J. Peterson, L.R. Ashkenas, L.W. Cooper, C.N. Dahm, W.K. Doods and N.B. Grimn, (2011). Nitrous oxide emission from denitrification in stream and river networks. PNAS 108(1): 214-219.

Bergey, D.H. and J.G. Holt, (1994). Bergey's manual of determinative bacteriology. Williams and Wilkins, Baltimore, USA.

Buller, N.B., (2004). Bacteria from Fish and Other Aquatic Animals - a practical identification manual Cabi Publishing, Cambridge MA.

Bunt, A.C., (1988). Media and mixes for containergrown plants. 2nd ed. Allen and Unwin, London.

Chen, S., J. Ling and J.P. Blancheton, (2006). Nitrification kinetics of biofilm as affected by water quality factors. Aquac. Eng. 34:179-197.

Connolly, K.T., (2010)Trebic optimization of a Backyard Aquaponic Food Production System ,McGuill University, Montreal, Canada

Diver S., (2000). Aquaponics - Integration of hydroponics with aquaculture. ATTRA Horticulture System Guide. http://attra. ncat. org/attra-pub/aquaponic . html.

Eaton, A.D. and M.A.H. Franson, (2005). Standard methods for the examination of water and waste water $21^{\text {st }}$ edn American Public Health Association, Washington DC.

Endut, A., N. Jusoh, W.B. Ali, Nik Wan and A. Hassan, (2009). Effect of flow rate on water quality parameters and plant growth of water spinach (Ipomoea aquatica) in an aquaponics recirculation system, Desal. Wat. Treat, 5: 19282.
Fred W., (2002). Recirculating Aquaculture Systems: An Overview of Waste Management. Proceedings of the $4^{\text {th }}$ International Conference, 57-68.

Ghaly, A., M. Kamal and N. Mahmoud, (2005). Phyto remediation of aquaculture wastewater for water recycling and production of fish feed, Environ. Int. 31: 1-13.

Hach company, (2003). DR/4000 Spectrophotometer Procedures Manual, $11^{\text {th }}$ ed. Hach Company, USA,

Jenkins, D., M.G. Richard and G.T. Daigger, (2004). Manual on the Causes and Control of Activated Sludge Bulking, Foaming, and Other Solids Separation Problems, 3rd ed. Lewis Publishers, New York.

John, H. and W. Fred, (2012). Biological Filters: Trickling and RBC Design. http://nsgd.gso.uri.edu/ vsgcpc98001/ vsgcpc 98001_part6.pdf.

Jones, S., (2002). Evolution of aquaponics. Aquaponics J. 6: 14-17.

Joye, S.B. and Hollibaugh, J.T., Influence of sulphide inhibition of nitrification on nitrogen regeneration in sediments. Sci. 270(1995), 623-625.

Kim, Y.M., D. Park, D.S. Lee and J.M. Park, (2007). Instability of biological nitrogen removal in a cokes wastewater treatment facility during summer. J. Hazard. Matter. 141: 27-32

King, K.R., G.J. Flick Jnr, D.D. Merle, S.A. Smith, and C.W. Coale Jnr, (2004). Identification of Bacterial Pathogens in Biofilms of Recirculating Aquaculture Systems, Aqu. Food Prod. Tech., 13: 1, 125-133.

Lennard, W. and B. Leonard, (2006). A comparison of three different hydroponic sub-systems (gravel bed, floating and nutrient film technique) in an aquaponics test system, Aquacult, Int. 14(6): 539-550

Leonard, N., J.P. Blancheton and J.P. Guiraud, (2000). Populations of heterotrophic bacteria in an experimental recirculatig aquaculture system, Aquacul. Eng., 22(1-2): 109-120.

Ling, J. and S. Chen, (2005). Impact of organic carbon on nitrification performance of different biofilters. Aquac. Eng. 33: 150-162.

Mao, Y., L.R. Bakken, L. Zhao and A. Frostegard, (2008). Functional robustness and gene pools of a wastewater nitrification reactor. Comparison of dispersed and intact biofilms 
when stressed by low oxygen and low $\mathrm{pH}$. FEMS. Microbiol. Ecol.

Masser, M.P., J. Rakocy and T.M. Losordo, (1999). Recirculating aquaculture tank production systems management of recirculating systems. SRAC Publication, 452.

Michaud, L., J.P. Blancheton, V. Bruni, and R. Piedrahita, (2006). Effect of particulate organic carbon on heterotrophic bacterial populations and nitrification efficiency in biological filters. Aquac. Eng. 34: 224-233.

Mills, D. (1987). The Marine Aquarium. Virginia: Salamander Books Ltd.

Mishra, G.P. and A.K. Yadav, (1978). A comparative study of physico-chemical characteristics of lake and river water in central India. Hydrobiol., 59(3):275-278.

Mongirdas, V., A. Kusta, (2006). Oxygen mass balance in a recirculation aquaculture system for raising European Wells (Silurus glanis L). Ekologija 4: 58- 64.

Noophan, P., P. Paopuree, K. Kanlayaras, S. Sirivithayapakorn and S. Techkarnjanaruk, (2009). Nitrogen Removal Efficiency at Centralized Domestic Wastewater Treatment Plants in Bangkok, Thailand. Env. Asia 2: 30-35.

Pagand, P., J.P. Plancheton and C.A. Casellas, (2000). Model for predicting the quantities of dissolved inorganic nitrogen released in effluents from a sea bass (Dicentrarchus Labrax) recirculating water system. Aquacul. Eng., 22: 137-153.

Papatryphon, E., J.S. Petit, H.M.G. Vander Werf, J. Kaushik, C. Kanyarushoki, (2005). Nutrient balance modeling as a tool for environmental management in aquaculture: the case of trout farming in France. Environ. Manag. 35(2): 161174.

Petit, J, (1986). Lapprovisionnement en eau, le traitement et le recyclage en aquaculture. In: G. Barnabd (Editor), Aquaculture Vol.I, Technique et Documentation Lavoisier, Paris, 46-180.

Rakocy, J. (1999b). The status of aquaponics, Part 2. Aquacult Magazine 25: 64-70.

Rakocy, J., (1999a). The status of aquaponics: The combined culture of fish and plants in recirculating systems. Part 1 Aquacult Magzine 25(12): 65p. www.aquaponics.com /hobby cf.htm.
Rakocy, J.E., M.P. Masser, T.M. Losordo, (2006). Aquaponics- Integrating Fish and Plant. Recirculating Aquaculture Tank Production Systems, SRAC Publication 454, (Retrieved from http://etension.ag.uidaho.edu/twinfalls

Ren, Y.X., L. Yang, and X. Liang, (2014). The characteristics of a novel heterotrophic nitrifying and aerobic denitrifying bacterium, Acinetobacter junii YB, Biores. Tech., 171:1-9.

Sace, C.F. and K.M. Fitzsimmons, (2013). Vegetable production in a recirculating aquaponics using Nile tilapia (Oreochromis niloticus) with and without freshwater prawn (Macrobrachium rosenbergii). Acad. J. Agric. Res. 1(12): 236-250

Satoh, H., N. Okabe and Y. Watanabe, (2000). Significance of substrate $\mathrm{C} / \mathrm{N}$ ratio on structure and activity of nitrifying biofilms determined by in situ hybridization and the use of microelectrodes. Water Sci. Technol. 41: 317321.

Stief, P., M. Poulsen, L.P. Nielsen, H. Brix and A. Schramm, (2009). Nitrous oxide emission by aquatic macrofauna. PNAS 106(11): 4296-4300.

Tangonan, G.T.R., (2012). Direction for the Innovation Clusters. Congressional Commission on Science and Technology and Engineering. http;//www.comste.gov.ph.

Villaverde, S., F. Fdz-Polanco and P.A. García, (2000). Nitrifying biofilm acclimation to free ammonia in submerged biofilters, Start-up influence .Water Res. 34, 602-610.

Whitman, K.A., (2004). Finfish and Shellfish Bacteriology manual: Techniques and Procedures, Iowa State Press, USA.

Wortman, S.E., (2015). Crop physiological response to nutrient solution electrical conductivity and $\mathrm{pH}$ in an ebbandflowhydroponicsystem.Sci.Hortic.(Amsterda m)194:34-42.

http://dx.doi.org/10.1016/j.scienta. 2015. 07.045.a

Yamamoto, T., K. Takaki, T. Koyama and K. Furukawa, (2008). Long-term stability of partial nitrification of swine wastewater digester liquor and its subsequent treatment by Anammox, Bioresource, Technol., 99(14): 64196425. 